JKM (Jurnal Kebidanan Malahayati),Vol 7,No.4.Oktober 2021,

ISSN (Print) 2476-8944 ISSN (Online) 2579-762X, Hal 857-864

\title{
TEMPE DAPAT MENINGKATKAN KADAR HEMOGLOBIN (HB) PADA IBU HAMIL
}

\author{
Nelly Indrasari ${ }^{*}$, dan Firda Agustina ${ }^{2}$ \\ 1,2Jurusan Kebidanan Politeknik Kesehatan Tanjungkarang \\ Korespondensi email : nellyindrasari@poltekkes-tjk.ac.id
}

\section{ABSTRACT THE EFFECT OF TEMPE IN INCREASING HEMOGLOBIN (HB) LEVELS IN PREGNANT WOMEN}

Background: Anemia is one of the indirect causes of death of pregnant women, therefore the condition of anemic pregnant women can have an impact on Low Birth Weight Babies. Efforts to prevent anemia in pregnancy can be given with pharmacological and non-pharmacological therapies. Pharmacological therapy has side effects such as stomach discomfort, nausea, difficulty in defecating, and black stools. While the non-pharmacological therapy that we can give to accelerate the increase in hemoglobin levels of pregnant women is one of them by consuming tempe (Fathonah, 2016).

The purpose of the study: to determine the effect of tempeh consumption on the increase in hemoglobin levels in pregnant women with anemia at the Karta Raharja Public Health Center.

Research method: This study uses a quasi-experimental or quasi-experimental method. In this study, the population was all pregnant women in the Kartaraharja Health Center in 2020, while the sample was 36 pregnant women. The sampling method of this study uses a non-probability sampling technique with purposive sampling. Intervention was carried out in the form of giving tempeh for 15 days, then after that the hemoglobin levels were checked again. Analysis of the data using the T-Dependent statistical test.

Results: From the results of the research conducted, the average hemoglobin level in the intervention group before being given tempeh was $9.4278 \mathrm{gr} \%$, after being given tempeh the average hemoglobin level rose to $10,7111 \mathrm{gr} \%$. The average increase in hemoglobin levels of pregnant women after the intervention was 1.2833 gr\%. The results of data analysis in the control group were $9.7111 \mathrm{gr} \%$, while the average hemoglobin level after monitoring was $10.4333 \mathrm{gr} \%$. The average increase in the control group was $0.7222 \mathrm{gr} \%$.

Conclusion: from this study it can be concluded that there is an effect of consuming tempeh and iron on anemic pregnant women at the Karta Raharja Tulang Bawang Barat Health Center in 2020.

Suggestion: it is hoped that later it will become a place of knowledge for mothers so that they have good and right abilities and vice versa. The results of this study can be continuously improved to provide more relevant information and learning references regarding the treatment with non-pharmacological therapy of Anemia as an effort to prevent and support the achievement of Maternal Health in Tulang Bawang Barat, which is also very useful for scientific development in the future. And it is necessary to hold a program that helps handling cases of anemia, especially in Tulang Bawang Barat Regency which coordinates with other sectors such as religious leaders, community leaders, besides that health education is still provided by health workers and cadres to young women and women of childbearing age about danger of anemia.

Keywords : Anemia, Hemoglobin, Tempe

\section{ABSTRAK}

Latar Belakang: Anemia merupakan salah satu faktor penyebab tidak langsung kematian ibu hamil, oleh karena itu kondisi ibu hamil anemia dapat berdampak pada BBLR. Upaya untuk mencegah terjadinya anemia pada kehamilan dapat diberikan dengan terapi farmakologi dan non farmakologi. Terapi farmakologi memberikan efek samping seperti perut terasa tidak enak, mual, susah buang air besar, dan feses berwarna hitam. Sedangkan terapi non farmakologi yang dapat kita berikan untuk mempercepat peningkatan kadar $\mathrm{Hb}$ ibu hamil salah satunya dengan konsumsi tempe (Fathonah, 2016).

Tujuan penelitian: untuk mengetahui pengaruh konsumsi tempe terhadap kenaikan kadar hemoglobin pada ibu hamil yang mengalami anemia di puskesmas Karta Raharja.

Metode penelitian: Penelitian ini menggunakan metode quasi eksperiment atau eksperimen semu.Dalam penelitian ini populasinya adalah seluruh ibu hamil yang ada di Puskesmas Kartaraharja tahun 2020, sampel sebanyak 36 ibu hamil. Metode sampling penelitian ini menggunakan non-probability dengan teknik sampling purposive sampling. Dilakukan intervensi berupa pemberian tempe selama 15 hari, kemudian setelah itu dilakukan pengecekan kadar Hemoglobin kembali. Analisis data menggunakan uji statistik uji T-Dependen. 
Hasil: Dari hasil penelitian yang dilakukan, rata-rata kadar Hemoglobin pada kelompok intervensi sebelum diberikan tempe adalah 9,4278 gr\%, setelah diberikan tempe rata-rata kadar hb naik menjadi $10.7111 \mathrm{gr} \%$. Peningkatan rata-rata kadar $\mathrm{Hb}$ ibu hamil setelah diberikan intervensi sebesar $1,2833 \mathrm{gr} \%$. Hasil analisis data pada kelompok kontrol 9,7111 gr\%, sedangkan rata-rata kadar $\mathrm{Hb}$ setelah dilakukan pemantauan sebesar $10.4333 \mathrm{gr} \%$. Peningkatan rata-rata pada kelompok kontrol $0.7222 \mathrm{gr} \%$.

Kesimpulan: dari penelitian ini dapat disimpulkan bahwa adanya pengaruh konsumsi tempe dan Fe pada ibu hamil mengalami anemia di Puskesmas Karta Raharja Tulang Bawang Barat Tahun 2020.

Saran : diharapkan nantinya menjadi wadah pengetahuan bagi ibu sehingga memiliki kemampuan yang baik dan benar begitu pula sebaliknya. Hasil penelitian ini dapat terus ditingkatkan untuk memberikan informasi dan referensi pembelajaran yang lebih relevan mengenai penanganan dengan terapi non farmakologi Anemia sebagai salah satu upaya pencegahan dan mendukung tercapainya Kesehatan Ibu di Tulang Bawang Barat, juga sangat berguna untuk pengembangan keilmuan dikemudian hari. Serta perlu diadakannya suatu program yang membantu penanganan kasus Anemia pada, khususnya di Kabupaten Tulang Bawang Barat yang berkoordinasi dengan sektor lain seperti Tokoh Agama, Tokoh Masyarakat, disamping itu pendidikan kesehatan yang tetap diberikan oleh tenaga kesehatan serta kader kepada remaja putri maupun PUS/WUS tentang bahaya Anemia.

Kata Kunci : Anemia, Hemoglobin, Tempe

\section{PENDAHULUAN}

Anemia pada ibu hamil menjadi penyebab utama terjadinya perdarahan dan infeksi yang merupakan faktor kematian ibu. Angka Kematian Ibu (AKI) merupakan salah satu indikator keberhasilan layanan kesehatan di suatu Negara dan berpengaruh terhadap kualitas Sumber Daya Manusia (SDM) di Indonesia (Wiknjosastro, 2005). Anemia adalah suatu kondisi dimana terdapat kekurangan sel darah merah atau hemoglobin.Kadar $\mathrm{Hb}<11 \mathrm{~g} / \mathrm{dl}$ (pada trimester I dan III) atau < 10,5 g/dl (pada trimester II) (Litbangkes, 2018).

Anemia pada ibu hamil merupakan salah satu masalah kesehatan di Indonesia yang sering dialami wanita usia subur terutama oleh ibu hamil. lbu hamil yang menderita anemia mempunyai resiko kematian ibu pada masa antenatal, perinatal, masa postnatal sertaberesiko melahirkan bayi dengan berat badan lahir rendah (BBLR).Pada keadaan ini banyak ibu yang meninggal karena perdarahan, infeksi sehingga akan meningkatkan angka kematian ibu dan anak (Cakrawati, 2012). Di negara berkembang, anemiamenjadi perhatian yang serius karena dampaknya pada ibu maupun janinberkontribusi terhadap kematian maternal (J.B. Sharma, 2010). Anemia pada wanita usia subur menjadi perhatian World Health Organization dan ditargetkan dapat direduksi sebanyak $50 \%$ pada tahun 2025.

Anemia pada ibu hamil umumnya merupakan anemia relatif akibat perubahan fisiologis tubuh selama kehamilan yaitu adanya hemodilusi. Ibu hamil dapat mengalami anemia karena kebutuhan zat besi selama hamil meningkat untuk pertumbuhan janin. Anemia kehamilan dapat dicegah apabila seorang ibu mempunyai asupan nutrisi yangbagus sebelum hamil sehingga mempunyai cadangan zat besi di dalam tubuh (AbuOuf \& Jan, 2015).

Anemia dalam kehamilan dapat berdampak buruk terhadap mortalitas dan morbiditas ibu maupun janin. Hasil dari kehamilan dengan anemia di antaranyaintra uterine growth retardation (IUGR), lahir prematur, berat bayi lahir rendah(BBLR), dan peningkatan risiko kematian neonatus. Efek anemia kehamilan padaibu di antaranya sesak nafas, kelelahan, palpitasi, gangguan tidur, meningkatkan risiko pendarahan saat persalinan, preeklamsia, dan sepsis (Noran and Mohammed, 2015; Sharma and Meenakshi, 2010). Dampak buruk anemia kehamilan pada janin di negara berkembang lebih tinggi, sedangkan di negara industri prognosis perinatal tidak berhubungan dengan anemia kehamilan (Kozuma, 2009).

Menurut (WHO, 2012) prevalensi anemia pada ibu hamil mencapai $41 \%$ di dunia, dan Asia menduduki peringkat kedua di dunia setelah Afrika dengan presentase prevalensi penderita anemia dalam kehamilan $48,2 \%$. Menurut penelitian Pusponegoro dan Anemia Worl Map, pada tahun 2012 indonesia merupakan salah satu Negara di asia dengan kejadian anemia dalam kehamilan cukup tinggi sebesar $51 \%$.

$\mathrm{Di}$ Indonesia dilaporkan bahwa penyebab tingginya Angka Kematian lbu (AKI) adalah perdarahan 32,34\%, hipertensi $15,16 \%$, infeksi $3,3 \%$, gagguan system peredaran darah (jantung) $4,4 \%$, gangguan metabolic (DM, dII) 4,4\%, dan lainlain 40,4\% (Lampung, 2018).

Dari data tahun 2018, prevalensi anemia pada ibu hamil di Indonesia sebesar $48,9 \%$ yang 


\section{JKM (Jurnal Kebidanan Malahayati),Vol 7,No.4.Oktober 2021, ISSN (Print) 2476-8944 ISSN (Online) 2579-762X, Hal 857-864}

terdiri dari anemia pada ibu hamil umur 15-24 sebesar $84 \%$, umur $23-34$ sebesar $33,7 \%$ umur 35 44 sebesar $33,6 \%$ dan umur $45-54$ sebesar $24 \%$. Data tersebut menunjukan bahwa peningkatan prevalensi anemia pada ibu hamil dari tahun 2013 sebesar 37,1\% (Litbangkes, 2018).

Upaya untuk mencegah terjadinya anemia pada kehamilan dapat diberikan dengan terapi farmakologi dan non farmakologi. Terapi farmakologi contohnya seperti pemberian tablet $\mathrm{Fe}$ untuk meningkatkan kadar $\mathrm{Hb}$ pada ibu hamil, terapi ini memberikan efek samping seperti perut terasa tidak enak, mual, susah buang air besar, dan feses berwarna hitam. Sedangkan terapi non farmakologi yang dapat kita berikan untuk mempercepat peningkatan kadar $\mathrm{Hb}$ ibu hamil salah satunya dengan pemberian konsumsi tempe (Fathonah, 2016).

Tempe goreng dipilih sebagai pangan yang difortifikasi karena kelompok ekonomi bawah konsumsi tempe lebih tinggi dibanding kelompok ekonomi menengah keatas, berdasarkan data yang akan dilakukan adalah penambahan zat besi dan vitamin A karena berbagai penelitian menunjukkan bahwa pada anemia defisiensi besi, juga ditemukan defisiensi vitamin $A$, Defisiensi vitamin $A$ menyebabkan gangguan absorpsi besi, metabolisme besi, dan gangguan mobilisasi besi dari cadangan besi untuk eritropoiesis.

Menurut (Indonesia, 2004), tiap 100 gram tempe mengandung protein $41.7 \mathrm{gram}$ dan zat besi $4 \mathrm{mg}$, sedangkan penelitian lain yang dilakukan astuty mendapatkan hasil bahwa setiap 100 gram tempe mengandung $87 \mathrm{gram}$ protein dan zat besi 4,6 mg, setara dengan Angka Kebutuhan Gizi (AKG) protein dan besi pada ibu hamil.

Berdasarkan prasurvei yang dilakukan pada bebrapa puskesmas di Tulang Bawang Barat antara lain puskesmas Dayamurni 20 data ibu hamil anemia dan Karta Raharja 40 data ibu hamil anemia. Di dapatkan hasil populasi terbesar ibu hamil yang mengalami anemia berada di puskesmas Karta Raharja dengan hasil 7 dari 10 orang $70 \%$ dari ibu hamil yang mengalami anemia .

Angka kejadian Anemia pada kehamilan di Provinsi Lampung adalah sebesar 11,67\%. Jika perempuan mengalami anemia akan sangat berbahaya pada waktu hamil dan melahirkan. Perdarahan merupakan salah satu faktor penyebab terbesar angka kematian ibu (Lampung, 2018).

Prevalensi anemia dalam kehamilan di kabupaten Tulang Bawang Barat sebesar 30\% dari antara seluruh ibu hamil anemia di kabupaten lain. Jika ibu hamil mengalami anemia akan sangat berbahaya pada waktu hamil dan melahirkan.
Perempuan dengan anemia sangat berpotensi melahirkan bayi dengan berat badan rendah (kurang dari 2,5 kg). selain itu anemia dapat menyebabkan kematian pada ibu maupun bayi pada waktu proses persalinan (Barat, 2018).

Puskesmas merupakan tempat pelayanan kesehatan masyarakat yang terletak di Tulang Bawang Barat merupakan tempat pelayanan KIA dengan jumlah ibu hamil. Bidan puskesmas mengatakan seluruh ibu hamil yang memeriksakan kehamilan nya di puskesmas telah mendapatkan tablet Fe dan Vitamin C secara teratur. Hasil wawancara kepada ibu hamil yang memeriksakan diri di puskesmas mengatakan ibu tetap menderita anemia, sebagai besar ibu hamil tidak mengetahui bahwa pemberian tempe merupakan sumber makanan nabati yang dapat membantu untuk meningkatkan kadar hemoglobin ibu.

Berdasarkan latar belakang masalah tersebut maka peneliti tertarik melakukan penelitian tentang pengaruh pemberian tempe terhadap kenaikan kadar $\mathrm{Hb}$ pada ibu hamil anemia di Puskesmas Karta Raharja Tulang Bawang Barat 2020.

\section{METODE PENELITIAN}

Penelitian ini menggunakan metode quasi eksperiment. Penelitian ini dilakukan dengan cara dilakukan dengan rancangan pretest-posttest with control group design yaitu pada kelompok perlakuan dan kelompok kontrol diawali dengan pretest (pengukuran awal) kadar haemoglobin pada ibu hamil dan setelah pemberian dilakukan pengukuran kembali (posttest).

Populasi dalam penelitian ini adalah ibu hamil anemia di Puskesmas Kartaraharja Tulang Bawang Barat 2020.

Besar sampel dihitung dengan menggunakan rumus Federer, yaitu:

$$
(t-1)(r-1) \geq 15
$$

Sampel pada penelitian ini sebanyak 16 orang ibu hamil anemia. Jumlah sampel ditambah $10 \%$ sebesar $1,6=2$ untuk kemungkinan drop out.Jadi sampel kelompok yang akan diberikanintervensi tempe dan fe sejumlah 18 orang ibu hamildan sampel yang diberikan fe saja sejumlah 18 orang ibu hamil kelompok kontrol. Sehingga sampel yang di ambil yaitu 36 ibu hamil anemia di Puskesmas Karta Raharja Tulang Bawang Barat 2020.

Agar karakteristik sampel tidak menyimpang dari populasinya, maka penentuan kriteria masing- 
masing kelompok sampel ditentukan dengan kriteria inklusi dan eksklusi sebagai berikut:

a. Kriteria inklusi

1) Ibu hamil Ibu hamil trimester $2 \& 3$ yang bersedia menjadi responden

2) Ibu hamil yang mengalami anemia di puskesmas karta raharja

3) Ibu hamil yang tidak menderita gangguan ginjal, penyakit gondok, dan asam urat

b. Kriteria Ekslusi

1) Ibu hamil yang tidak bersedia jadi responden

2) Ibu hamil yang tidak mengalami anemia di Puskesmas Karta Raharja

3) Ibu hamil yang menderita gangguan ginjal, penyakit gondok, dan asam urat.

Metode sampling penelitian ini menggunakan non-probability dengan teknik sampling purposive sampling. Setiap responden diobservasi, di wawancara dan dilakukan pemeriksaan Hemoglobin. Kemudian Peneliti menjelaskan tujuan dan manfaat penelitian dilanjutkan dengan membuat persetujuan (informed consent) dilakukannya penelitian kepada responden. Intervensi yang diberikan mengikuti tatalaksana umum dari Kementerian Kesehatan Indonesia, yaitu selama minimal 2 minggu (14 hari) bagi ibu hamil Trimester 2, berupa pemberian konsumsi Tempe pada responden. Setelah tempe diberikan selama 15 hari berturut-turut, selanjutnya peneliti melakukan pengukuran kadar $\mathrm{Hb}$ kembali. Analisis data yang digunakan dalam penelitian ini adalah t-test dependent.

\section{HASIL DAN PEMBAHASAN}

Karakteristik Responden

Berdasarkan tabel 1 dibawah didapatkan bahwa umur responden di wilayah kerja Puskesmas
Karta Raharja Tulang Bawang Barat yang tertinggi adalah responden dengan kisaran umur 20-35 tahun sebanyak $91,7 \%$ atau 33 orang. Sebagian besar responden memiliki paritas multigravida sebanyak $67 \%$ atau 24 orang. Pendidikan tertinggi responden adalah setingkat SMP yaitu sebanyak $41,7 \%$ atau 15 orang. Dan rata-rata pekerjaan responden yang tertinggi adalah sebagai IRT sebanyak $47,2 \%$ atau 17 orang.

Tabel 1.

Karakteristik responden ibu hamil Di Puskesmas Karta Raharja

\begin{tabular}{lcc}
\hline Karakteristik Responden & $\mathbf{N}$ & $\%$ \\
\hline Umur & & \\
$<20$ atau $>30$ tahun & 3 & $8,3 \%$ \\
$20-35$ tahun & 33 & $91,7 \%$ \\
Paritas & & \\
Primipara & 12 & $33 \%$ \\
Multipera & 24 & $67 \%$ \\
Pendidikan & & \\
SD & 7 & $19,4 \%$ \\
SMP & 15 & $41,7 \%$ \\
SMA & 6 & $16,7 \%$ \\
Diploma & 8 & $22,2 \%$ \\
Pekerjaan & & \\
IRT & 17 & $47,2 \%$ \\
Pedagang & 8 & $22,2 \%$ \\
Petani & 6 & $16,7 \%$ \\
PNS & 5 & $13,9 \%$ \\
\hline Jumlah & 36 & $100 \%$ \\
\hline
\end{tabular}

\section{Analisis Univariat}

Kadar $\mathrm{Hb}$ pada ibu hamil anemia sebelum diberikan tempe dan Fe pada kelompok intervensi.

Tabel 2.

Nilai rata-rata kadar haemoglobin pada ibu hamil dengan anemia sebelum diberikan intervensi tempe di Puskesmas Karta Raharja Tulang Bawang Barat

\begin{tabular}{lccccc}
\hline Kadar Hb Sebelum Intervensi & N & Min & Max & Mean & Std.Deviation \\
\hline Kelompok kontrol & 18 & 8,80 & 10.50 & 9.7111 & 0.47265 \\
Kelompok intervensi & 18 & 7,50 & 10.50 & 9,4278 & 0.72583 \\
\hline
\end{tabular}

Dari tabel 2 diatas didapatkan rata-rata kadar $\mathrm{Hb}$ pre-test pada kelompok kontrol adalah 9,71 dan kelompok intervensi adalah 9,48 gr\%, dengan kadar $\mathrm{Hb}$ tertinggi pada kelompok kontrol dan kelompok intervensi sebesar $10.50 \mathrm{gr} \%$.

Kadar $\mathrm{Hb}$ pada ibu hamil anemia sesudah di berikan intervensi/pemberian tempe
Dari tabel 3 dibawah maka didapatkan ratarata kadar $\mathrm{Hb}$ sesudah diberikan intervensi (posttest) pada kelompok kontrol adalah $10.43 \mathrm{gr} \%$ dengan standard devisiasi 0,49823. Sedangkan pada kelompok eksperimen rata-rata kadar $\mathrm{Hb}$ dari post-test adalah $10.71 \mathrm{gr} \%$ dengan standar deviasi sebesar 0.76688.Dari data diatas didapatkan bahwa nilai rata-rata $\mathrm{Hb}$ kelompok intervensi/perlakuan lebih tinggi di bandingkan kelompok kontrol. 
Tabel 3.

Nilai rata-rata kadar haemoglobin pada ibu hamil dengan anemia Sesudah diberikan intervensi tempe di Puskesmas Karta Raharja Tulang Bawang Barat

\begin{tabular}{lccccc}
\hline Kadar Hb Stelah Intervensi & N & Min & Max & Mean & Std.Deviation \\
\hline Kelompok kontrol & 18 & 9,80 & 11.50 & 10.4333 & 0.49823 \\
Kelompok intervensi & 18 & 9,50 & 11,90 & 10,7111 & 0.76688 \\
\hline
\end{tabular}

Analisis Bivariat

Tabel 4.

Perbedaan kadar hb sebelum dan sesudah pemberian tempe pada ibu hamil dengan Anemia Di Puskesmas Karta Raharja Tulang Bawang Barat

\begin{tabular}{lccccc}
\hline \multirow{2}{*}{ Variabel } & \multirow{2}{*}{$\mathbf{N}$} & \multicolumn{2}{c}{ Mean } & Sig. (2-Tailed) & P Value \\
\cline { 3 - 6 } & 18 & Pre & Post & Amean & \\
\hline Kelompok intervensi & 18 & 9,7111 & 10,7111 & 1,2833 & \multirow{2}{*}{000} \\
Kelompok kontrol & 10.4333 & 0.7222 & \\
\hline
\end{tabular}

Dari hasil pengujian diatas menunjukan bahwa terdapat selisih rata-rata kadar $\mathrm{Hb}$ ibu hamil pada kelompok intervensi sebesar -1.2833 gr\% sedangkan kelompok kontrol sebesar -0,7222 gr\% dengan nilai Sig. 0.000.Dari data diatas didapatkan bahwa nilai rata-rata $\mathrm{Hb}$ kelompok intervensi/perlakuan lebih tinggi di bandingkan kelompok kontrol.

\section{PEMBAHASAN}

Kadar Hemoglobin pada lbu Hamil dengan Anemia Sebelum Diberikan Intervensi tempe dan Fe (Pre-test)

Kandungan protein pada tempe dapat disetarakan dengan kandungan dalam daging, malah lebih banyak mengandung protein. Kandungan pada tempe terbukti kualitasnya lebih baik dibandingkan kedelai, karena kadar protein yang larut dalam air akan mengakibatkan meningkatnya enzim proteolitik (Widianarko, 2002).

Teori diatas sejalan dengan penelitian yang dilakukan oleh (Novianti, 2019) menemukan ada pengaruh pemberian susu tempe terhadap kenaikan kadar hemoglobin pada ibu hamil TM III di kota Bengkulu.

Berdasarkan survey yang dilakukan pada kasus anemia pada ibu hamil dalam penelitian ini disebabkan oleh kurangnya asupan makanan yang mengandung banyak zat besi, serta masih banyak ibu hamil yang melewatkan untuk mengkonsumsi tablet $\mathrm{Fe}$ yang diberikan bidan atau puskesmas.

Oleh karena itu dapat disimpulkan bahwa untuk meningkatkan kandungan zat besi dan mengurangi kasus anemia pada ibu hamil peneliti memberikan tempe sebagai makanan tambahan, karena pada $100 \mathrm{gr}$ tempe mengandung $20,8 \mathrm{mg}$ zat besi. Dengan adanya kandungan tersebut peneliti berharap dapat membantu mengatasi anemia dan dengan tetap patuh mengkonsumsi tablet $\mathrm{Fe}$.

Kadar Hemoglobin Ibu Hamil dengan Anemia Sesudah Diberikan Intervensi tempe (Post-test)

Berdasarkan teori adanya peningkatan yang lebih besar rata-rata kadar hemoglobin pada kelompok eksperimen dikarenakan responden diberikan tempe yang didalamnya terkandung protein 20,8 g, zat besi $4 \mathrm{mg}$, , fosfor $326 \mathrm{mg}$, kalsium $155 \mathrm{mg}$, air 55,3\%, Sehingga mampu meningkatkan kadar hemoglobin pada ibu hamil Haryanto, 2007).

Hal tersebut sesuai dengan penelitian yang dilakukan (Mansur, 2017) menemukan ada nya pengaruh pemberian brownis tempe terhadap kenaikan HB pada ibu hamil di wilayah Puskesmas Pratiwi, Kecamatan Mariso Penelitian.

Hasil penelitian ini sejalan dengan penelitian yang telah dilakukan oleh wahyuni Mansur, yang berjudul pengaruh pemberian brownis tempe terhadap kenaikan kadar hemoglobin pada ibu hamil di wilayah puskesmas pratiwi Hasil kadar hemoglobin sebelum dilakukan intervensi pada responden kelompok kasus 2 yaitu 9,86 gr/dl dan mengalami peningkatan setelah dilakukan intervensi menjadi $13,36 \mathrm{gr} / \mathrm{dl}$ jadi terdapat peningkatan kadar hemglobin sebesar 3,5 gr/dlhasil.

Menurut pendapat peneliti berdasarkan hasil penelitian didapatkan kadar hemoglobin pada ibu hamil berbeda-beda hal tersebut dikarenakan oleh kebiasaan ibu hamil selama memenuhi nutrisi ibu hamil yang mereka konsumsi dalam sehari hari.

Pengaruh pemberian tempe terhadap peningkatan kadar HB pada ibu hamil anemia 
Zat besi dalam tempe yang sudah dalam bentuk ferro ( $\mathrm{Fe} 2+)$ sehingga lebih mudah diserap tubuh tanpa dipengaruhi faktor penghambat zat besi dan tidak membutuhkan reduksi. Pada proses pencernaan besi dalam bentuk ferro ( $\mathrm{Fe} 2+)$ tersebut akan dioksidasi didalam usus untuk berikatan dengan apferritin, kemudian ditransformasikan menjadi ferritin dan dibebaskan ke dalam plasma darah yang kemudian terjadi proses pengkajian transferin dan diangkat ke sumsum tulang belakang untuk bergabung membentuk hemoglobin (Rona, 2015).

Berdasarkan penelitian yang dilakukan oleh (Mansur, 2017), menemukan ada nya pengaruh pemberian brownis tempe terhadap kenaikan HB pada ibu hamil di wilayah Puskesmas Pratiwi, Kecamatan Mariso Penelitian. Berdasarkan penelitian yang dilakukan oleh Novianti, 2019) menemukan ada pengaruh pemberian susu tempe terhadap kenaikan kadar hemoglobin pada ibu hamil TM III di kota Bengkulu.

Menurut pendapat peneliti berdasarkan hasil penelitian di dapatkan bahwa kenaikan kadar hemoglobin berbeda-beda dikarenakan nutrisi makanan yang di konsumsi tiap hari nya berbedabeda sehingga kadar hb yang lebih tinggi pada konsumsi temped an tablet Fe disebab kan oleh absorbs makanan juga. Berdasarkan hasil penelitian ini, maka peneliti menganjurkan pada ibu hamil yang mengalami anemia untuk mengonsumsi tempe sebagai makanan tambahan selain tablet $\mathrm{Fe}$ untuk meningkatkan kadar $\mathrm{Hb}$ ibu hamil yang mengalami anemia.

\section{SIMPULAN}

Berdasarkan hasil penelitian dapat disimpulkan bahwa adanya pengaruh konsumsi tempe dan Fe pada ibu hamil mengalami anemia.

\section{SARAN}

Dengan memberikan perlakuan pada periode sebelum kehamilan maka akan menjadi wadah pengetahuan sehingga menjadikan ibu memiliki kemampuan yang baik dan benar begitu pula sebaliknya. Hasil penelitian ini dapat terus ditingkatkan untuk memberikan informasi dan referensi pembelajaran yang lebih relevan mengenai penanganan dengan terapi non farmakologi Anemia sebagai salah satu upaya pencegahan dan mendukung tercapainya Kesehatan Ibu di Tulang Bawang Barat, juga sangat berguna untuk pengembangan keilmuan dikemudian hari. Diadakannya suatu program yang membantu penanganan kasus Anemia pada, khususnya di Kabupaten Tulang Bawang Barat yang berkoordinasi dengan sektor lain seperti Tokoh Agama, Tokoh Masyarakat, disamping itu pendidikan kesehatan yang tetap diberikan oleh tenaga kesehatan serta kader kepada remaja putri maupun PUS/WUS tentang bahaya Anemia.

\section{DAFTAR PUSTAKA}

Abu-Ouf, N. M., \& Jan, M. M. (2015). The impact of maternal iron deficiency and iron deficiency anemia on child's health. Saudi Medical Journal, $36(2)$. https://doi.org/10.15537/smj.2015.2.10289

Adawiyah, A. R. (2013). Faktor yang berhubungan dengan kejadian Anemia pada ibu hamil dipuskesmas Kecamatan Setiabudi. Universitas Muhammadiyah.

Amin Fauzan, agustino zulys dan R. B. (2017). Fortifikasi Dan Ketersediaan Zat Besi Pada Bahan Pangan Berbasis Kedelai Menggunakan Besi Edta, Glisinat, Fumarat, Dan Suksinat. Jurnal ITEKIMA, 1(1).

Amini, A., Pamungkas, C. E., \& Harahap, A. P. H. P. (2018). USIA IBU DAN PARITAS SEBAGAI FAKTOR RISIKO YANG MEMPENGARUHI KEJADIAN ANEMIA PADA IBU HAMIL DI WILAYAH KERJA PUSKESMAS AMPENAN. Midwifery Journal: Jurnal Kebidanan UM. Mataram, 3(2). https://doi.org/10.31764/mj.v3i2.506

Anggraini, D. D. (2018). Faktor Predisposisi lbu Hamil dan Pengaruhnya terhadap Kepatuhan Mengkonsumsi Tablet Besi (FE) dan Anemia pada Ibu Hamil. STRADA JURNAL ILMIAH KESEHATAN, 7(1). https://doi.org/10.30994/sjik.v7i1.141

Ari. (2009). Penyakit yang di alami ibu hamil. Jakarta: Salemba Medika.

Arini, L. D. D. (2019). Pengaruh Pemberian Tablet Ferrum ( $\mathrm{Fe}$ ) dengan Kadar Hemoglobin pada Ibu Hamil Trimester III. Biomedika, 12(1). https://doi.org/10.31001/biomedika.v12i1.399 Arisman. (2010). Gizi Dalam Daur Kehidupan. Jakarta: EGC.

Ariyani, R. (2016). Faktor-Faktor Yang Mempengaruhi Kejadian Anemia Pada Ibu Hamil Trimester III Di Wilayah Kerja Puskesmas Mojolaban Kabupaten Sukoharjo. Naskah Publikasi, 1(1).

Astawan, M. (2004). Tetap Sehat dengan Produk Makanan Olahan. Solo: Tiga Serangkai.

Astria. (2019). Masalah gizi pada ibu hamil. Yogyakarta: PT. PUSTAKA BARU.

Astuti, R. d. (2013). Kadar tembaga (cu) dan seng (zn) tikus sprangue dewley anemia defisiensi besi yang mendapat suplementasi tempe 


\section{JKM (Jurnal Kebidanan Malahayati),Vol 7,No.4.Oktober 2021, \\ ISSN (Print) 2476-8944 ISSN (Online) 2579-762X, Hal 857-864}

terfortifikasi zat besi dan vitamin A. Prosiding seminar nasional 2013.

Astuti, R. d. (2013). Kadar tembaga (cu) dan seng (zn) tikus sprangue dewley anemia defisiensi besi yang mendapat suplementasi tempe terfortifikasi zat besi dan vitamin A. Prosiding seminar nasional 2013.

Astuti, R. d. (2013). Kadar tembaga (cu) dan seng (zn) tikus sprangue dewley anemia defisiensi besi yang mendapat suplementasi tempe terfortifikasi zat besi dan vitamin A. Prosiding seminar nasional 2013.

Astuti, R. d. (2013). Kadar tembaga (cu) dan seng (zn) tikus sprangue dewley anemia defisiensi besi yang mendapat suplementasi tempe terfortifikasi zat besi dan vitamin A. Prosiding seminar nasional 2013.

Barat, D. T. (2018). Profil Dinas Kesehatan Tulang Bawang Barat. Lampung: Dinas Kesehatan Provinsi Lampung.

Cakrawati, M. N. (2012). Bahan Pangan, Gizi dan Kesehatan. Bandung: Alfabeta.

Fathonah, S. (2016). Gizi \& Kesehatan untuk Ibu Hamil. Jakarta: Erlangga.

Ginting Munthe, N. B., Siregar, G. . G., Sembiring, I. M., \& . N. (2021). PENGARUH KONSUMSI SUSU TEMPE TERHADAP KADAR HAEMOGLOBIN PADA IBU HAMIL TRIMESTER III. JURNAL KESMAS DAN GIZI (JKG), 3(2). https://doi.org/10.35451/jkg.v3i2.637

Hartono, J. (2017). Metodologi Penelitian Bisnis: Salah Kaprah dan PengalamanPengalaman. Yogyakarta: BPFE.

Haryanto. (2007). Budidaya Kacang Panjang. Jakarta: Swadaya.

Huda, A. (2012). Faktor Resiko Karakterisrtik Ibu Hamil Dengan Kejadian Anemia Di Puskesmas Jenawi Kabupaten Karanganyar.

Indonesia, D. K. (2004). Badan Penelitian dan Pengembangan Kesehatan Departemen Kesehatan Republik Indonesia. Jakarta: Depkes RI.

J.B. Sharma, M. S. (2010). Anemia in Pregnancy. JIMSA October-Desember 201023 (4) , 253260.

Kasmidjo, R. (1990). Tempe, Mikrobiologi dan Biokimia Pengolahan serta Pemanfaatannya. Yogyakarta: Universitas Gadjah Mada.

Kesehatan, D. (2018). Profil DInas Kesehatan Tulang Bawang Barat. Tulang Bawang Barat: Dinas Kesehatan .

Kozuma, S. (2009). Approaches to anemia in pregnancy. Research and reviews JMAJ 52(4) , 214-218.
Lampung, D. K. (2018). Profil Dinas Kesehatan Provinsi Lampung. Lampung: Dinkes Provinsi Lampung.

lis, S. d. (2008). Masa Kehamilan dan Persalinan. Jakarta: PT. Elex Media Komputindo.

Lisa. (2014). Hubungan Asupan Energi, Frekuensi Antenatal Care Dan Ketaatan Konsumsi Tablet Fe Dengan Kejadian Anemia Pada Ibu Hamil Di Puskesmas Wenang Kota Manado.

Litbangkes. (2018). Riset Kesehatan Dasar (Riskesdas). Jakarta: Kemenkes RI.

Lulu. (2009). Faktor Yang Berhubungan Dengan Status Anemia Pada Asuhan Antenatal Di Puskesmas Kecamatan Pasar Minggu Jakarta Selatan. Jakarta: FKM UI.

Mansur, W. (2017). Pengaruh Pemberian Brownies Tempe Subtitusi Wortel (Daucus Carota L.) Terhadap Kadar Hemoglobin (Hb) Pada Ibu Hamil Anemia Di Wilayah Kerja Puskesmas Pertiwi Kecamatan Mariso Kota Makassar. Makassar: UIN Alauddin Makassar.

Manuaba. (2008). Pengantar Kuliah obstetri. Jakarta: EGC.

Mardliyanti, E. (2020, Maret). Fortifikasi Garam dan Zat Besi, Strategi Praktis dan Efektif Menanggulangi Anemia Gizi Besi.

Murtini. (2004). Efektifitas Suplementasi Tablet Besi dan Vitamin C Terhadap Kadar Hemoglobin Ibu Hamil di Wilayah Kerja Puskesmas Bantimurung Kabupaten Maros. Makasar: Universitas Hasanuddin.

Notoatmodjo, S. (2018). Methode Penelitian Kesehatan. Jakarta: Rineka Chipta.

Novianti, A. S. (2019). Pengaruh Pemberian Susu Tempe Terhadap Kadar Haemoglobin Pada Ibu Hamil Tm lii Di Kota Bengkulu. Journal Of Midwifery, 7(1) , 23-29.

Nurhidayati, R. D. (2013). Analisis Faktor Penyebab Terjadinya Anemia Pada Ibu Hamil Diwilayah Kerja Puskesmas Tawangsari Kabupaten Sukoharjo. Naskah Publikasi.

Prawirohardjo, S. (2010). Diagnosis kehamilan. Jakarta: PT. Bina Pustaka.

Prawirohardjo, S. (2018). Diagnosis kehamilan. Jakarta: PT. Bina Pustaka.

Prayitno, N. S. (2014). Sikap Kepatuhan Konsumsi Tablet Fe Terhadap Kadar Hb Ibu Hamil Yang Berkunjung ke Puskesmas Kecamatan Palmerah Kota Administrasi Jakarta Barat. Jakarta.

Proverawati. (2011). Anemia dan Anemia Kehamilan. Yogyakarta: Nuha Medika.

Rona, F. R. (2015). Faktor-Faktor yangBerhubungan dengan Status Gizi Anak 
Balita di Wilayah Kerja PuskesmasNanggalo Padang. Padang: Universitas Andalas.

Salman, Y., Novita, S., \& Burhanudin, A. (2016). Pengaruh Proporsi Tepung Terigu, Tepung Tempe Dan Tepung Daun Kelor (Moringa oliefera) Terhadap Mutu (Protein Dan Zat Besi) Dan Daya Terima Mie Basah. Jurkessia, 6(5).

Susilowati, K. (2016). Gizi Dalam Daur Kehidupan. Bandung: PT Refika Aditama.

Ulfiana, E., Yuliandani, F. A., Dewi, R. K., \& Ratri, W. K. (2019). Pengaruh Pemberian Ubi Jalar Ungu terhadap Peningkatan Kadar Haemoglobin Pada Ibu Hamil Trimester III. JURNAL KEBIDANAN, $9(1)$. https://doi.org/10.31983/jkb.v9i1.4027

Tarwoto, W. (2007). Buku Saku Anemia Pada Ibu Hamil. Jakarta: Trans Info Media.

WHO. (2012). Iron deficiency anemia : Assesment, prevention and control. USA: World Health Organization.

Widianarko. (2002). Tips Pangan "Teknologi, Nutrisi, dan Keamanan Pangan". Jakarta: Grasindo.

Wiknjosastro, H. (2005). Ilmu Kebidanan. Ed. 3. Jakarta: Yayasan Bina Pustaka .
Windari, L., Lisnawati, N., \& Herutomo, T. (2018). FAKTOR-FAKTOR YANG MEMPENGARUHI KEJADIAN ANEMIA PADA IBU HAMIL DI KECAMATAN JATILUHUR KABUPATEN PURWAKARTA. Journal of Holistic and Health Sciences, 2(1). https://doi.org/10.51873/jhhs.v2i1.24

Wulandari Sidharta, L. D., \& Susanto, J. (2017). Suplementasi Tempe Meningkatkan Status Besi dan Perkembangan Anak. Sari Pediatri, 18(3).

https://doi.org/10.14238/sp18.3.2016.169-74

Yuniwati, Y. (2018). PENGARUH PEMBERIAN SUSU TEMPE TERHADAP KADAR HAEMOGLOBIN PADA IBU HAMIL TRIMESTER III. JURNAL MEDIA KESEHATAN, $7(2)$. https://doi.org/10.33088/jmk.v7i2.242

Yuwanti, Y. (2019). Pengaruh Pemberian Tempe terhadap Kadar Hemoglobin pada Mencit. Jurnal Kebidanan Harapan Ibu Pekalongan, 6.

https://doi.org/10.37402/jurbidhip.vol6.iss2.6 4 